NBER WORKING PAPER SERIES

\title{
FIRM-SPECIFIC INFORMATION AND THE EFFICIENCY OF INVESTMENT
}

\author{
Anusha Chari \\ Peter Blair Henry \\ Working Paper 12186 \\ http://www.nber.org/papers/w12186
}
NATIONAL BUREAU OF ECONOMIC RESEARCH
1050 Massachusetts Avenue
Cambridge, MA 02138
April 2006

Chari: University of Michigan Business School; 701 Tappan Street, Ann Arbor, MI 48109-1234; achari@umich.edu. Henry: Stanford University, Graduate School of Business; Stanford, CA 94305-5015; pbhenry@stanford.edu. Henry gratefully acknowledges the financial support of a National Science Foundation CAREER award and the John and Cynthia Fry Gunn Faculty Fellowship. We thank Jack Glen for providing us with data. For helpful comments we thank Rui Albuquerque, Steve Buser, Menzie Chinn, Laura Kodres, Richard Roll, Paul Romer, Jeffrey Wurgler, and seminar participants at the AEA Annual Meetings, Claremont, Federal Reserve Bank of Dallas Conference on Globalization, LACEA-Madrid, Maryland, Michigan, MIT, NBER, Stanford, Wharton, The IMF Annual Research Conference, UCLA, WFA, and the World Bank. Any remaining errors are our own. The views expressed in this paper are solely ours and do not represent the views of the National Science Foundation. The views expressed herein are those of the author(s) and do not necessarily reflect the views of the National Bureau of Economic Research.

(C2006 by Anusha Chari and Peter Blair Henry. All rights reserved. Short sections of text, not to exceed two paragraphs, may be quoted without explicit permission provided that full credit, including $\odot$ notice, is given to the source. 
Firm-Specific Information and the Efficiency of Investment Anusha Chari and Peter Blair Henry

NBER Working Paper No. 12186

April 2006

JEL No. E, F, G

\begin{abstract}
We use a new firm-level dataset to examine the efficiency of investment in emerging economies. In the three-year period following stock market liberalizations, the growth rate of the typical firm's capital stock exceeds its pre-liberalization mean by an average of 5.4 percentage points. Cross-sectional changes in investment are significantly correlated with the signals about fundamentals embedded in the stock price changes that occur upon liberalization. Panel data estimations show that a 1-percentage point increase in a firm's expected future sales growth predicts a 4.1-percentage point increase in its investment; country-specific changes in the cost of capital predict a 2.3-percentage point increase in investment; firm-specific changes in risk premia do not affect investment.

Anusha Chari

Department of Economics

University of Michigan

701 Tappan Street

Ann Arbor, MI 48109

achari@umich.edu

Peter Blair Henry

Stanford University

Graduate School of Business

Littlefield 277

Stanford, CA 94305-5015

and NBER

pbhenry@stanford.edu
\end{abstract}




\section{Introduction}

Do the investment decisions of firms in emerging economies reflect information about the fundamentals of those firms? On the one hand, there is little reason to expect an affirmative answer to this question, because stock price movements in emerging economies generally do not convey much firm-specific information (Morck, Yeung and Yu, 2000). If managers in emerging economies make investment decisions in accordance with changes in stock prices, but the prices contain little information about the underlying firms, then investment will also be divorced from firm-specific fundamentals.

On the other hand, the firm-specific information contained in stock prices tends to rise as countries move towards greater capital market openness (Li, Morck, Yang, and Yeung, 2004). And, with few exceptions, emerging economies continue to move rapidly in that direction (Stulz, 1999, 2005). For example, in the late 1980s and early 1990s, several developing countries liberalized their stock markets, allowing foreign investors to purchase shares for the first time. Moreover, when these liberalizations occur, publicly traded firms in the liberalizing countries experience large stock price changes, and firm-specific fundamentals help to explain much of the cross-firm variation in price changes (Chari and Henry, 2004).

Since liberalization-induced stock price movements do contain information about firmspecific fundamentals, it is natural to ask whether those fundamentals have predictive power for investment. In this paper, we examine whether the real investment decisions of firms in emerging economies respond to the changes in fundamentals implicitly signaled by the liberalization-induced stock price changes of those firms.

In a rational asset pricing world, a change in a firm's stock price reflects a change in either or both of the following: (1) the firm's cost of capital, and (2) the firm's expected future 
profitability. In theory, stock market liberalization affects only the cost of capital, and it does so through two channels. The first is a common shock to all firms in the economy-a fall in the risk-free rate as the country moves from financial autarky to integration with the rest of the world. All else equal, the common shock to the cost of capital will increase the average investment rate of all firms.

The second channel is a firm-specific "beta" effect. With liberalization, the relevant benchmark for pricing the risk of individual stocks switches from the local stock market index to a world market index. Consequently, the equity-risk premium falls for firms whose returns are less correlated with the world market than they are with the local market and vice versa. Given the common shock, the firm-specific shock implies that firms whose equity premia fall should invest even more than those whose premia rise.

While in theory stock market liberalizations primarily affect the cost of capital, in practice they often coincide with other economic reforms that increase total factor productivity, economic growth, and the profitability of investment (Henry, 2000a, 2003). Therefore, it is important to control for the possibility that reform-induced changes in expected future profitability may drive any post-liberalization changes in investment. We use a simple openeconomy model of Tobin's $Q$ to decompose firms' post-liberalization changes in investment into: (1) changes in expected future profitability, (2) the change in the risk-free rate, and (3) changes in equity premia. We then use the cross sectional variation in our five-country, 369-firm data set to identify the economic and statistical significance of each of the three effects.

Panel data estimations show that a one-percentage-point rise in our measure of a firm's expected future profitability results in a 2.9- to-4.1-percentage-point increase in the growth rate of the firm's capital stock, depending on the specification. The common shock to firms' cost of 
capital is also important, as it generates a 2.3-percentage-point per-year increase in capital stock growth and is statistically significant in almost every specification. In contrast, firm-specific changes in equity premia have an economically trivial effect on changes in investment and are statistically insignificant in every specification.

The remainder of the paper proceeds as follows. Section 1 explains the contribution of our paper relative to previous work. Section 2 presents a simple model that generates testable empirical predictions. Section 3 describes the data and presents descriptive findings. Section 4 outlines the empirical methodology and presents the main results. Section 5 presents robustness checks. Section 6 concludes.

\section{Related Literature}

Broadly speaking, previous work expresses two views about the wisdom of opening capital markets in emerging economies to foreign investors. The first view argues that liberalization promotes efficient resource allocation. Removing restrictions on international capital movements permits resources to flow from capital-abundant developed countries, where expected returns are low, to capital-scarce emerging economies, where expected returns are high. In theory, the flow of resources into the capital-scarce countries should reduce their cost of capital, increase investment, and raise output (Fischer, 2003; Obstfeld, 1998; Rogoff, 1999; Summers, 2000).

The second view sees the first as unsubstantiated. This view asserts that instead of promoting a more efficient international allocation of capital, liberalizations generate speculative capital flows that are divorced from the fundamentals and have no discernible effect on investment, output, or any other real variable with nontrivial welfare implications (Bhagwhati, 
1998; Rodrik, 1998; Stiglitz, 1999, 2002).

Recent work in finance tries to resolve the difference of opinions by examining the economic impact of stock market liberalizations. For example, previous work uses aggregate data to document three central facts. When countries liberalize their stock markets: (1) the cost of capital falls (Bekaert and Harvey, 2000; Henry 2000a; Martell and Stulz, 2003); (2) aggregate investment booms (Henry, 2000b); and (3) the growth rate of GDP per capita increases (Bekaert, Harvey, and Lundblad, 2004; Levine, 2001).

While aggregate data provide some support for the view that liberalization leads to a more efficient allocation of capital, they have at least two shortcomings. First, it is not clear how much confidence we can have in an empirical result that attributes an economy-wide investment boom to stock market liberalization, a policy change that directly affects only those firms listed on the stock market. Since the link from liberalization to growth works through investment, it too, must be treated with skepticism (Henry, 2003). Second, the rise in aggregate investment may suggest an efficient reallocation of capital between countries, but it says nothing about the efficiency of capital allocation within countries. Questions about within-country allocative efficiency cannot be answered with aggregate data that, by definition, provide no within-country variation in investment.

This paper addresses the first shortcoming by using firm-level data. Instead of using aggregate investment as a proxy for the investment of the firms affected by liberalization, we use the investment of only those firms that are listed on the stock market. Since publicly traded firms are impacted directly by liberalization, our data provide a tighter link to the theory than aggregate investment data. 
The paper addresses the second shortcoming by developing a new identification strategy. Again, observing an increase in aggregate investment following liberalizations does not tell us whether markets are efficiently allocating capital within a country. The key idea is that the stock price changes that occur upon liberalization embody signals about firm-specific fundamentals such as the cost of capital and expected future cash flows. While recent evidence confirms that the stock price changes that occur during liberalizations do contain such firm-specific information (Chari and Henry, 2004), the more pressing economic question is whether investment responds accordingly. The next section of the paper develops a simple model that allows us to address the question in a systematic fashion.

\section{A Simple Model of Firm-Level Investment, Stock Prices, and Liberalization}

This section generates empirically testable, cross-sectional predictions about liberalization, firm-level investment, and firm-specific information. It does so by analyzing what happens to the desired investment of an all equity-financed firm when the country in which that firm resides moves from a regime where foreigners are not permitted to own domestic shares, and domestic residents cannot invest abroad, to one where all stocks are fully tradable. ${ }^{1}$

On the financial side, we make the usual assumptions under which the capital asset pricing model (CAPM) holds. On the real side, we assume a standard neoclassical production framework: All firms are price takers, the production function is linear homogeneous in capital and labor, and the cost of installing capital is linear homogeneous in $I$ and $K$. Under these realside assumptions, marginal Tobin's $Q$ and average $Q$ are equal (Hayashi, 1982). Finally, for expositional convenience, assume that all investors have an identical coefficient of relative risk

\footnotetext{
${ }^{1}$ The central intuition of the analysis extends to the case of non-symmetric liberalizations. See Chari and Henry (2004) for details.
} 
aversion, $\gamma$. The frictionless capital markets framework highlights the key margins at which liberalization affects firms' investment decisions, but the empirical analysis in Section 4C.1 considers financial frictions.

Consider the standard investment equation for a firm in a small country in autarky:

$$
\left(\frac{I}{K}\right)_{i}=a+b Q_{i}
$$

Since marginal and average $Q$ are equal by assumption, $Q_{i}$ may be expressed as $\frac{V_{i}}{K_{i}}$ where $V_{i}$ is the stock market value of the firm and $K_{i}$ is the replacement cost of its capital stock. Since $V_{i}$ is simply the present discounted value of the firm's expected future cash flow, let $\tilde{\pi}_{i}$ denote the firm's stochastic cash flow, which is expected to grow exponentially at the rate $g_{i}$ so that:

$$
Q_{i}=\frac{V_{i}}{K_{i}}=\frac{\bar{\pi}_{i}}{K_{i}\left[r+\theta_{i}-g_{i}\right]}
$$

Where $r$ is the economy's risk-free interest rate, $\bar{\pi}_{i}$ the expected value of $\tilde{\pi}_{i}$, and $\theta_{i}$ the risk premium investors require to hold shares of firm $i$ in equilibrium.

Now suppose that the country opens its stock market to the rest of the world and also allows its residents to invest abroad. Interest rates, risk premia, and expected future growth rates may all change instantaneously in response to the news. Let $r^{*}, \theta_{i}^{*}$ and $g_{i}^{*}$ be the postliberalization values of those fundamentals. Note that the stock of capital, $K_{i}$, adjusts more slowly because it takes time to buy and install new machines. Hence, define "on-impact" as a period of time that is long enough for asset prices to adjust to liberalization but too short for the capital stock to do so as well, and let $Q_{i}^{*}$ denote the on-impact value of $Q$ for firm $i$. The onimpact change in $Q$ will drive the subsequent adjustment in the firm's capital stock. Since $Q$ has 
changed, the capital stock must also adjust to reestablish equilibrium.

Specifically, the liberalization-induced change in the firm's desired investment, which we denote $\Delta\left(\frac{I}{K}\right)_{i}^{*}$, must equal $\Delta Q_{i}^{*} \cdot{ }^{2}$ This implies that:

$$
\Delta\left(\frac{I}{K}\right)_{i}^{*}=b \Delta Q_{i}^{*}
$$

Combining (2) and (3) and performing a few steps of algebra shows that the relationship between the post-liberalization change in investment and the on-impact change in $Q$ may be written as:

$$
\Delta\left(\frac{I}{K}\right)_{i}^{*}=\Delta Q_{i}^{*}=\lambda_{i}\left[\left(r-r^{*}\right)+\left(\theta_{i}-\theta_{i}^{*}\right)+\left(g_{i}^{*}-g_{i}\right)\right]
$$

where $\lambda_{i}=\frac{b \bar{\pi}_{i}}{K_{i}\left[\left(r+\theta_{i}-g_{i}\right)\left(r^{*}+\theta_{i}^{*}-g_{i}^{*}\right)\right]}$. Since the pre- and post-liberalization risk premia

$\left(\theta_{i}\right.$ and $\theta_{i}^{*}$ ) are not directly observable, so it takes one more step of algebra to deliver an empirically testable equation.

Recall that under the CAPM, $\theta_{i}=\left\{\operatorname{Cov}\left(R_{i}, R_{M}\right) / \operatorname{Var}\left(R_{M}\right)\right\} \bar{R}_{M}$, where the variable $R_{M}$ is the excess return on the domestic market portfolio, $\bar{R}_{M}$ its expected value, and $\operatorname{COV}\left(R_{i}, R_{M}\right)$ the historical covariance of firm $i$ 's stock return with the local market. Similarly, $\theta_{i}^{*}=\left\{\operatorname{Cov}\left(R_{i}, R_{W}\right) / \operatorname{Var}\left(R_{W}\right)\right\} \bar{R}_{W}$, where the subscript $W$ indexes the world market portfolio. Using these definitions and the fact that the excess return on the market is equal to the coefficient of relative risk aversion times the variance of the market return, a little algebra reveals that $\theta_{i}-\theta_{i}^{*}=\gamma\left[\operatorname{COV}\left(R_{i}, R_{M}\right)-\operatorname{COV}\left(R_{i}, R_{W}\right)\right]$. So we can write $\theta_{i}-\theta_{i}^{*}=\gamma D I F C O V$, where

\footnotetext{
${ }^{2}$ Adjustment costs may deter firms from installing capital until $Q$ returns to its pre-liberalization level, but the onimpact change in $Q$ will still drive the direction and magnitude of the change in the capital stock.
} 
$\operatorname{DIFCOV}=\left[\operatorname{COV}\left(R_{i}, R_{M}\right)-\operatorname{COV}\left(R_{i}, R_{W}\right)\right]$.

Finally, using the definition of $D I F C O V$ we may rewrite equation (4) as

$$
\Delta\left(\frac{I}{K}\right)_{i}^{*}=\lambda_{i}[\underbrace{\left(r-r^{*}\right)+\gamma D I F C O V_{i}}_{\text {Change in Cost of Capital }}+\overbrace{\left(g_{i}^{*}-g_{i}\right)}^{\text {Change in Growth Rate of Earnings }}] .
$$

The $\lambda_{i}$ term in front of the brackets on the right-hand-side of (5) is a firm-specific scaling factor with some technical implications for empirical estimation, which we discuss in Section 4. The three terms inside the brackets merit discussion now because they provide testable predictions by highlighting the forces that drive the reallocation of capital.

The first term is the common shock, $\left(r-r^{*}\right)$. It shows that the post-liberalization change in investment depends on the change in the risk-free interest rate. All else equal, investment will rise if $r^{*}$, the world risk-free rate, is lower than $r$, the autarky rate, and vice versa. Importantly, the common shock term has no subscript, because it has the same effect on all firms in the economy.

The second term is the firm-specific risk sharing effect $\left(D I F C O V_{i}\right)$. Firm-specific changes in investment should vary inversely with firm-specific changes in the equity premium. When a liberalization occurs, it alters the set of systematic risks faced by the representative investor. This means that the relevant benchmark for pricing the risk of individual stocks switches from the local stock market index to a world market index. Consequently, liberalization reduces the equity premium for firms whose returns are more correlated with the local market than they are with the world market, and vice versa. Given the first term, the second implies that high DIFCOV firms will experience a larger fall in their cost of capital than low DIFCOV firms. All else equal, firms that experience a larger fall in their cost of capital will also invest 
more. In other words, while liberalization reduces the risk-free rate, and all firms should invest more on average, we should observe even larger increases in investment by firms whose shares become less risky to hold in the aftermath of liberalization.

The third term in equation $(5),\left(g_{i}^{*}-g_{i}\right)$, indicates that the larger the increase in the growth rate of a firm's expected future cash flow, the greater its post-liberalization change in investment. Now, as the previous three paragraphs explain, if stock market liberalization affects resource allocation, it does so primarily through its impact on the cost of capital. Nevertheless, liberalizations coincide with important economic reforms such as trade liberalizations and inflation stabilization programs (Frankel and Romer, 1999; Henry, 2002). In other words, postliberalization changes in investment may stem from a fall in the cost of capital (driven by stock market liberalization) or an increase in profitability (driven by other reforms). The next section turns to the data we employ to address these issues.

\section{Data and Descriptive Findings}

This section introduces the data. Subsection 3A explains how we use the data to construct the variables we need to test the predictions of the model in Section 1. Subsection 3B presents descriptive findings: basic facts in 3B.1, time series facts in 3B.2, and cross-sectional facts in $3 \mathrm{~B} .3$.

Estimating equation (5) requires data on capital stock growth rates, cash flow growth rates, and covariances of stock returns. We obtain firm-level data on capital stocks, cash flows, and stock returns from the International Finance Corporation's Corporate Finance Database. Singh et al. (1992) and Booth et al. (2001) provide exhaustive descriptions of this database. Our discussion focuses on the details relevant to this paper.

Between 1980 and 1994, the International Finance Corporation (IFC) collected annual 
balance sheet and income statement data for a maximum of the 100 largest publicly traded, nonfinancial firms in eleven developing countries: Argentina, Brazil, India, Jordan, Korea, Malaysia, Mexico, Pakistan, Thailand, Turkey, and Zimbabwe. The IFC employed two screening criteria in deciding the sample of countries for its database: (1) quality data had to be available for a reasonably large sample of firms; and (2) developing countries from each continent had to be represented. For several countries the sample begins after 1984, because the early years did not contain data of sufficiently high quality.

In order for a country in the IFC database to be included in our sample, it must satisfy one additional criterion: The IFC data for that country must exist before and after the year in which the country liberalized its stock market. To identify the date of each country's first stock market liberalization we employ the same procedure as Henry (2000a). Official policy decree dates are used when they are available. When no policy decree dates are available, we employ two indirect methods. First, the establishment of the first country fund permitting foreign ownership. Second, a 10-percent increase in the IFC's investability index; the index captures the ratio of the market capitalization of stocks that foreigners can legally hold to total market capitalization. Table 1 lists the liberalization dates for the five countries in the sample.

The before-and-after criterion, in combination with the short length of some countries' time series, reduces our sample to 369 firms spread across five countries: India, Jordan, Korea, Malaysia, and Thailand. Despite its modest size, this sample of firms is better suited to addressing the question of whether liberalization affects firms' investment decisions than competing databases such as Worldscope and Global Vantage. The reason is that Data from Worldscope and Global Vantage do not satisfy the before-and-after criterion. The median stock market liberalization date in the sample is 1988 (see Table 1), and Worldscope and Global 
Vantage contain little firm-level data before that time.

\section{A. Constructing Measures of Capital Stocks, Profitability, Covariances, and Tobin's $Q$}

The IFC database provides balance sheet information that we use to construct a time series on the growth rate of each firm's capital stock. For each firm, the database reports the nominal value of net fixed assets (the stock of property, plant, and equipment less depreciation) on an annual basis. In order to obtain the real growth rate of each firm's capital stock, the ideal adjustment procedure would deflate the percentage change in net fixed assets (NFA) by the rate of inflation of each firm's capital goods. Since no such capital goods data exist, we deflate using the Consumer Price Index (CPI) in three steps. First, we take the natural log of nominal NFA at time $t+1$ and subtract the natural $\log$ of NFA at time $t$. Second, we take the natural log of the CPI at time $t+1$ and subtract the natural log of the CPI at time $t$. Third, we subtract the second quantity from the first to produce the real growth rate of each firm's capital stock between year $t$ and $t+1$.

The database also contains income statement information that we can use to construct measures of the growth rate of expected future profitability. Specifically, we have to choose whether to use earnings or sales. We choose sales for the following reason. The data on earnings exhibit wild year-to-year fluctuations. In comparison, the sales growth numbers are relatively stable. Since sales revenues are relatively stable, the fluctuations in earnings suggest either: (1) implausibly large year-to-year fluctuations in unit costs; or (2) that firms manipulate their earnings numbers. In light of concern about point (2), and since firms have less incentive to manipulate sales than they do earnings, we feel more comfortable using sales. Having said that, using sales as a measure of profitability has some important limitations that we discuss in 
Section 4. We divide the nominal value of each firm's sales by the CPI to create a real index.

The IFC database also contains annual stock return data, which we use to compute the variable $D I F C O V$. Recall that $D I F C O V$ is the historical covariance of a firm's stock return with the local market index, minus the historical covariance of the firm's stock return with the world market index. Since the goal is to relate changes in investment — an annual variable — to changes in risk, we compute annual covariances. For each firm we compute the covariance of its annual, real-dollar-denominated, dividend-inclusive return with that of the local market. For each firm we also compute its annual, real-dollar-denominated, dividend-inclusive return with that of the MSCI World Total Return Index. Monthly covariances are notoriously fraught with measurement error (Fama and French, 2004). The signal-to-noise ratio in our annual covariance data is even lower. Section 4B.1 attempts to address the measurement error problem, and the conclusion explains why, in spite of measurement error, it is important to test whether changes in the cross-section of risk explain changes in the cross-section of investment.

For each firm in the sample, we also construct Tobin's $Q$. For the numerator we use the sum of the market value of equity and the book value of debt (current and long-term liabilities). We use book values of debt because the IFC database does not contain information on market values. In the absence of data on market values of debt, some U.S. studies convert book values to market values by capitalizing net interest payments using the yield on Moody's corporate A bond (Blanchard, Rhee, and Summers, 1993). Because we do not have data on corporate bond rates in these countries for the relevant time period, we cannot use such a conversion method. For the denominator of Tobin's $Q$ we use the book value of total assets.

The level of Tobin's $Q$ may not be directly comparable across countries, because of differences in accounting practices. For example, firms in India, Malaysia, and Jordan value 
assets using the practice of fair-market valuation in accordance with North American Generally Accepted Accounting Principles (GAAP). In contrast, Korea and Thailand rely on strict historiccost accounting as in Germany and Japan. In light of these differences, changes in $Q$ provide more compatible cross-country measures. We examine changes in $Q$ in the next subsection.

\section{B. Descriptive Findings}

Table 1 summarizes the essential characteristics of the data. Column 1 provides country names. Column 2 lists the year of each country's stock market liberalization. Column 3 gives the number of firms in each country. Column 4 shows that the stock market capitalization of the 369 firms in our sample constitutes about 40 percent of the total stock market capitalization of all publicly traded firms in these countries. This number suggests that the firms account for a nontrivial fraction of total economic activity, but the point should not be overstated; publicly traded firms account for a smaller fraction of the economy in these countries than they do in the U.S.

\section{B.1 Preliminary Facts About Liberalization, Changes in $Q$, and Changes in Investment}

The fifth and final column of Table 1 shows that the average firm experiences a 46.1percent jump in the value of Tobin's $Q$ during liberalization, but this fact merits further scrutiny. As mentioned earlier, we only have information on the book value of debt. Since liberalization has no impact on book values, it follows mechanically that changes in the market value of equity—stock prices—must drive the jump. To confirm that this is indeed the case we repeat the calculation in Column 5 using stock prices instead of Tobin's $Q$. This second calculation is consistent with the first. The average firm experiences a 51-percent jump in its stock price during the liberalization year. 
The jump in stock prices confirms a central prediction of the model in Section 2. The logical next issue is whether investment responds accordingly. This raises two questions. The first is time series in nature: Do we see a rise in the average investment rate of the firms in our sample? The second is cross-sectional: Is the size of the increase in investment positively correlated with the size of the stock price jump, that is to say, do the firms that experience the largest increase in stock prices also experience the largest increase in investment? The next two subsections address each of these questions in turn.

\section{B.2 Time Series Findings}

Figure 1 provides a preliminary answer to the time series question. It plots the average growth rate of the 369 firms' capital stocks in liberalization time: $t=[0]$ is the year in which liberalization occurs, $t=[+1]$ is the year immediately following the liberalization, and so on. The figure shows that the average firm's investment rises sharply in the three years immediately following a liberalization. ${ }^{3}$ Figure 1 is not entirely surprising since previous work documents that aggregate investment increases in the aftermath of liberalizations (Henry, 2000b). But previously published work uses aggregate (country-level) data, which consists of investment by both publicly traded and non-publicly traded firms. Since liberalization most directly affects the investment incentives of publicly traded firms, the firm-level effects documented in this paper appear more tenable.

Moreover, as one would expect, the firm-level effects are also larger. For instance, the growth rate of the average country's capital stock exceeds its pre-liberalization mean by an average of 1.1 percentage points per year in the three years after liberalization (Henry, 2003). In

\footnotetext{
${ }^{3}$ Consistent with this finding, Morck, Strangeland, and Yeung (2000) document a rise in capital intensity of production for widely held firms after liberalization in Canada.
} 
contrast, Figure 1 shows that the growth rate of the average firm's capital stock exceeds its preliberalization mean by an average of 3.8 percentage points per year over the same time period. A simple back-of-the-envelope calculation demonstrates the economic significance of the firmlevel numbers. Multiplying the firm-level capital-stock-growth deviation number, 3.8, by the elasticity of output with respect to capital (about one-third), gives a rough sense of its implication for the growth rate of firm output: about 1.3 percentage points per year.

It is important to remember that stock prices sometimes deviate from their fundamental values (Shiller, 1981, 2000). Ramping up investment in response to a stock price bubble can hardly be called efficient in a social welfare maximizing sense. ${ }^{4}$ In order to assess whether liberalization fosters inefficient investment, we examine the ex-post rate of return to capital. For each firm, we compute the flow return to the stock of capital as the ratio of earnings before interest and taxes to the value of net fixed assets. After computing this ratio for each of the 369 firms, we take a simple average and call it the rate of return to capital.

Figure 2 shows that the rate of return to capital actually increases from an average of 16.0 percent per year in the pre-liberalization period (years -3 to -1 ) to 24.3 percent per year in the post-liberalization period (years +1 to +3 ). While Figure 2 appears inconsistent with the notion of indiscriminate, bubble-driven investment, we would expect to see some decline in capital's rate of return as firms buy and install new machinery. Why does this not happen? Again, liberalizations may coincide with reforms that increase the profitability of investment. Figure 3 demonstrates the point. The growth rate of real sales and real earnings both increase sharply during liberalization episodes.

\footnotetext{
${ }^{4}$ See Baker, Stein, and Wurgler (2003), Blanchard, Rhee and Summers (1993), Fischer and Merton (1984), and Stein (2003) for an extensive discussion of efficient investment when stock prices deviate from fundamentals.
} 


\section{B.3 Cross-Sectional Findings}

There is no glaring evidence of inefficiency in the time series profiles of investment and the fundamentals. Yet for firms to invest efficiently, they must be discerning not only in the time series but also in the cross section. In turn, cross-sectional efficiency requires that firms' postliberalization investment decisions systematically reflect the signals about fundamentals that are embedded in the stock price changes that occur at liberalization.

Before providing a preliminary answer to the cross-sectional question-are changes in investment correlated with the changes in stock prices? - it is useful to review the rationale for raising the question in the first place. The paper began with the observation that liberalizationinduced stock price changes contain firm-specific information and proposed to investigate whether that information affects firms' investment decisions. Specifically, the goal is to decompose the correlation between changes in investment and the liberalization-induced stock price changes into something more fundamental: the correlation between changes in investment and the changes in discount rates and profitability that drive the stock price changes.

As a first step, we examine the simple correlation between the changes in firms' investment and their stock price change at liberalization (standard errors in parentheses; adjusted R-Squared=0.01; N=1185):

$$
\Delta\left(\frac{I}{K}\right)_{i t}=0.001+0.056 \text { STOCKPRICECHANGE }_{i}, t \in\{[0],[+1],[+2],[+3]\}
$$

As before, the variable $t$ indexes liberalization time. The variable $\Delta\left(\frac{I}{K}\right)_{i t}$ is defined as the growth rate of firm $i$ 's capital stock in year $t$ minus the average pre-liberalization growth rate of firm $i$ 's capital stock. The pre-liberalization average is calculated over the three-year period 
immediately preceding the liberalization $(t=[-3]$ to $t=[-1])$. The rationale for this construction is straightforward. Just as the stock price response to liberalization is a measure of news, analyzing firms' investment responses to that news requires a measure of the unexpected or abnormal growth rate of their capital stock relative to some benchmark. All else equal, in the instant before news of liberalization arrives, the pre-liberalization mean of the growth rate of a firm's capital stock is a reasonable forecast of its expected future growth rate. The variable STOCKPRICECHANGE is the liberalization-year percentage change in firm $i$ 's stock price.

The low value of R-squared indicates a lot of unexplained variation and might be interpreted as evidence of inefficiency, but it is important to remember that the principal objective of empirical work is to obtain dependable estimates of the true regression coefficients, not to achieve high values of R-squared (Gujarati, 1988, p. 186).

Bearing the caveat about R-squared in mind, equation (6) provides reasonable support for the theory. On average, the larger the impact of liberalization on a firm's stock price, the larger is its post-liberalization increase in investment. A simple calculation illustrates the economic significance of the correlation. As mentioned earlier, the average value of the liberalization-year stock price changes in our sample is 51 percent, so equation (6) predicts that the growth rate of the average firm's capital stock will exceed its pre-liberalization mean by an average of 2.9 percentage points (51 percent times 0.056 ) in the post-liberalization period. Again, the implication of this estimate for output growth is not small-about one percentage point per year.

While both the time series and the cross-sectional data suggest the empirical relevance of the question with which the paper began, the evidence presented so far is only preliminary. Again, neither Figure 1 nor equation (6) control for a host of factors, other than liberalization, that may drive the increase in investment. The next section addresses this subject. 


\section{Empirical Methodology and Results}

This section explains the empirical methodology and presents results. Subsection 4A presents the benchmark results. Subsection 4B takes a closer look at the role of the cost of capital in the results, and 4B.1 re-estimates the results using alternative measures of firm-specific changes in risk. Subsection 4C examines why changes in risk do not affect investment, and 4C.1 examines the potential impact of imperfect capital markets on the results.

The following equation from Section 2 shows how to decompose the post-liberalization changes in investment into the fundamentals that drive them:

(7) $\Delta\left(\frac{I}{K}\right)_{i}^{*}=\lambda_{i}\left[\left(r-r^{*}\right)+\gamma \operatorname{DIFCOV}_{i}+\left(g_{i}^{*}-g_{i}\right)\right]$.

The symbols inside the brackets show how the change in investment for each firm depends on the common shock of a change in interest rates (the intercept term) and changes in risk sharing and expected future growth rates (the slope terms).

The $\lambda_{i}$ term in front of the brackets is a firm-specific scaling factor that has some technical implications for empirical estimation. If the $\lambda_{i}$ 's were observable, we could transform the terms in brackets to yield an equation with constant coefficients. Since the $\lambda_{i}$ 's are not observable, it might seem natural to estimate equation (7) with a random coefficients model that takes them into account. The problem with random coefficients estimation is that it requires time variation in all of the right-hand-side variables and DIFCOV is purely cross-sectional. Since we cannot estimate (7) using random coefficients, and subsequent robustness checks (Section 5) show that ignoring the scale effect is inconsequential, we begin by estimating the following panel regression: 
(8)

$$
\begin{aligned}
& \Delta\left(\frac{I}{K}\right)_{i j t}=\text { CONSTANT }+ \text { COUNTRY }_{j}+a_{0} \Delta \text { SALESGROWTH } \\
& +a_{1} \sum_{\tau=1}^{3} \Delta \operatorname{SALESGROWTH} H_{i j t+\tau}+b_{0} D I F C O V+\varepsilon_{i j t}, t \in\{[0],[+1],[+2],[+3]\} .
\end{aligned}
$$

Equation (8) provides a practical regression specification that captures all of the qualitative features present in the structural decomposition of equation (7). The variable $\Delta\left(\frac{I}{K}\right)_{i j t}$ denotes the deviation of the capital stock growth of firm $i$ (in country $j$ ) from its firmspecific mean. Again, $t$ denotes years measured in liberalization time, as defined in Section 3B.2. For instance, $\Delta\left(\frac{I}{K}\right)_{i j[+1]}$ denotes the deviation, in the year following liberalization, of the growth rate of firm $i$ 's capital stock from its firm-specific mean. The intercept term, CONSTANT, measures the average value of the common shock to the cost of capital, after controlling for the country-specific effects captured by the dummy variable, COUNTRY .

The variable $\triangle S A L E S G R O W T H_{i j t}$ is the deviation of the growth rate of firm i's sales from its firm-specific mean in year $t$. It is our best proxy for "news"-changes in the growth rate of expected future profits. Just as the left-hand-side variable captures the "surprise" or abnormal change in capital stock growth, the sales variable captures the abnormal growth in sales. To control for the impact of current abnormal growth on investment we use the variable $\triangle S A L E S G R O W T H_{i j t}$. In theory, only changes in expected future growth should affect investment, but including changes in current growth proves useful when we examine the validity of the perfect capital markets assumption in Section 4C.1. To control for the impact of future abnormal growth on investment we use the sum of three leads of abnormal growth. For instance, when $t=[0]$, the summation variable takes on the value of cumulative abnormal growth in Years 
$[+1],[+2]$, and [+3]. It bears repeating that the sales growth variables control for shocks to current and expected future growth, whether they originate from economic reforms coincident with stock market liberalization or elsewhere.

The next term on the right-hand-side of (8) is the variable DIFCOV , which captures the impact of firm-specific changes in risk. Recall that DIFCOV is defined as the difference between the firm's historical covariance with the local and world markets. Even though DIFCOV does not vary over time for any given firm, it does vary across firms for any given time period. Equation (8) uses this cross-firm variation in DIFCOV for any given time period to estimate the effect of changes in risk. Equation (8) also estimates the effect of changes in expected profitability by making use of both the time series variation in sales growth within a firm, and the cross-sectional variation in sales growth across firms. To see this, simply note that the change-in-sales-growth variable has both a firm and a time subscript.

Turning at last to the error term, $\varepsilon_{i j t}$, it is important to note that since all firms in a given country are "clustered" around the same liberalization date, the correlation between individual firms' capital stock growth rate deviations may not be zero. If this is the case, the standard distributional assumptions about the error term, $\varepsilon_{i j t}$, no longer obtain. Accordingly, all of the regressions we estimate adjust for clustering in the computation of standard errors. The estimation procedure also corrects for heteroscedasticity across firms.

\section{A. Benchmark Empirical Results}

Table 2 reports the results from estimating equation (8). Column (1) reports the regression of changes in capital stock growth on a constant (the common shock), country-fixed effects, and no other controls. The coefficient on the constant is 0.041 and significant at the one- 
percent level. This means that in the post-liberalization period, the growth rate of the typical firm's capital stock exceeds its pre-liberalization mean by an average of 4.1 percentage points per year.

Column (2) reports the results of a regression on a constant and changes in current and future sales growth. The coefficient on changes in current sales growth is 0.229 and significant at the one-percent level. The coefficient on changes in future sales growth is 0.315 and also significant at the one-percent level. Both estimates are also economically significant. For instance, the estimate on changes in current sales growth indicates that a 10-percentage-point deviation of current sales growth from its pre-liberalization mean predicts that the typical firm's capital stock growth in the post-liberalization period will exceed its pre-liberalization mean by 2.29 percentage points (0.1 times 0.229$)$. Again, the estimate of the constant, 0.019 , is economically and statistically significant.

Column (3) reports the results of a regression on a constant and our measure of changes in risk sharing. The estimate of the constant in this specification is 0.028 and is significant at the one-percent level. The coefficient on changes in risk sharing is positive, as predicted by the theory, but it is statistically insignificant, and economically trivial. To see what trivial means, multiply the coefficient on changes in risk sharing $(0.037)$ by the average value of the variable for all the firms in the sample (0.015). This calculation shows that the average annual effect of risk sharing on the typical firm's capital stock growth is 0.00056 or 0.056 percentage points, which means that the effect on firm output growth is roughly 0.019 percentage points per annum.

Column (4) reports the results of the full-blown decomposition, a regression of changes in capital stock growth on a constant, changes in sales growth, and changes in risk. The constant is not significant in this regression. The estimate of the coefficient on the change in current sales 
is 0.316 , the coefficient on the change in future sales is 0.287 , and both are significant at the onepercent level. The estimate of the coefficient on changes in risk continues to be economically and statistically insignificant.

\section{B. Does the Cost of Capital Matter for Changes in Investment?}

While the estimated effect of changes in risk on changes in capital stock growth is economically trivial and statistically insignificant, the constant is meaningful and significant in 3 of the 4 regressions in Columns (1) through (4) of Table 2. The significance of the constant suggests that the common shock to the cost of capital affects the post-liberalization changes in investment. Having said that, interpreting a significant constant as the impact of the common shock is not straightforward. In theory, the constant captures the change in the risk-free rate as the country moves from closed to open capital markets. In practice, the constant might reflect the impact of an unobserved regime shift that has nothing to do with a change in the cost of capital.

In order to scrutinize whether changes in the cost of capital really matter, Column (5) of Table 2 reports the results of a regression that adds one more variable to the regression reported in Column (4). The additional variable is one we used in the preliminary cross-sectional analysis in Section 3B.3: the firm's stock price change during the liberalization year. The logic of this regression is as follows. Theory says that changes in stock prices are driven by changes in expected future profitability and changes in the cost of capital. Since we are controlling for changes in profitability with changes in current and future sales growth, a significant coefficient on the change-in-stock-prices variable would suggest a significant effect of the cost of capital on investment. 
Column (5) shows that the coefficient on the change in stock prices is 0.030 and significant at the 5 percent level. This is a smaller number than the simple univariate coefficient on stock price changes in Equation (6), but it is still economically significant and suggests that firms' post-liberalization changes in investment are significantly related to changes in their overall cost of capital.

It is also important to note that the constant is no longer significant in the specification reported in Column (5). If the significant constant in columns (1) through (3) reflects some spurious regime shift in investment that is unrelated to a change in the cost of capital, then the constant should not be affected by the inclusion of the change in stock prices as a right-hand-side variable, but this is not the case. To underscore the point, Column (6) reports the results from a regression of changes in capital stock growth on a constant and the change in stock price with no other controls. Again, the coefficient on the stock price change is significant, the constant is not.

To confirm that changes in risk play no role in guiding the post-liberalization allocation of investment, Column (7) of Table 2 reports the results of a final specification. We regress capital stock growth deviations on a constant, current sales growth deviations, future sales growth deviations, changes in risk, and changes in stock prices. The coefficient on the change in stock price is 0.042 and significant at the one-percent confidence level. The coefficients on current and future sales growth deviations are both significant at the one-percent level. The coefficient on changes in risk remains economically and statistically insignificant.

\section{B.1 Alternative Measures of Changes in Risk}

After controlling for expected future sales growth, stock prices matter for investment in almost every specification. Yet, the evidence so far suggests that changes in risk sharing have a 
negligible impact. The unavoidable conclusion would seem to be that if changes in the cost of capital do drive investment, the common shock to the cost of capital matters far more than firmspecific changes in risk premia. But it is possible that the significance of risk sharing is masked by measurement error.

One source of measurement error arises for the following reason. When countries liberalize, some publicly listed firms become eligible for foreign ownership (investible), while others remain off limits (non-investible). Data from the IFC's Emerging Markets Database show that $D I F C O V$ robustly explains the change in the cost of capital for investible firms, but is never significant for the non-investible ones (Chari and Henry, 2004). Therefore, it is possible that the changes in investment are significantly correlated with DIFCOV for the investible firms, but the relation is masked because the investible and non-investible firms are grouped together in our sample.

The investible and non-investible firms are grouped together in our sample, because the IFC Corporate Finance Database — the source of all the capital stock data—does not identify investible and non-investible firms. The Emerging Markets Database (EMDB) distinguishes between investible and non-investible firms, but it contains no capital stock data. By using the information in the EMDB, we were able to identify 61 investible and 28 non-investible firms in the IFC Corporate Finance database. We then reconducted the entire battery of tests for risk sharing on this sample of 89 firms. Again, the coefficient on DIFCOV did not reach significance.

Returning to the full sample, we conducted three additional tests for evidence that changes in risk affect changes in capital allocation. First, we constructed a new risk-sharing variable called DIFCOVI using the growth rate of real earnings instead of stock returns. Risk- 
sharing is defined here as the annual historical covariance of firm $i$ 's real earnings growth with the aggregate growth rate of real earnings on the local market, minus the annual historical covariance of firm $i$ 's real earnings growth with the aggregate growth rate of real earnings on the S\&P 500. Second, we sorted the firms by the sign of DIFCOV. Firms for whom DIFCOV is greater than zero we label DIFCOVPOSITIVE; firms for whom DIFCOV is less than zero we label DIFCOVNEGATIVE. Third, we ranked the firms in descending order of the magnitude of DIFCOV. Firms in the top 20 percent of the distribution we label DIFCOVHIGH; those in the bottom 20 percent we label DIFCOVLOW. After constructing our new risk-sharing variables, we replicated the regressions in Table 2 using the new measures in place of DIFCOV. None of the three new variables produced significant results.

\section{C. Why Do Changes in Risk Have No Impact on the Allocation of Capital?}

The failure of changes in risk to matter for the allocation of physical capital might suggest a "numb" (Morck, Yeung, and Yu, 2000) invisible hand incapable of responding to the signals about risk embedded in the liberalization-induced stock price changes. But an alternative explanation is that firms face financial constraints that hinder their ability to allocate capital in accordance with the neoclassical model of investment. In order to understand whether financing constraints affect the investment decisions of the firms in our sample, we take a closer look at the sensitivity of their investment to measures of current cash flow.

\section{C.1 Imperfect Capital Markets}

In a frictionless capital market world, only expected future cash flow should matter for investment. There is ample evidence, however, that current cash flow also exerts a significant 
influence (Fazzari, Hubbard, and Petersen, 1988; Hubbard, 1998). Furthermore, the results in Table 2 show that the post-liberalization decisions of firms in our sample are strongly influenced by current profitability. One possible explanation for this fact runs as follows: The growth rate of sales that occurs at liberalization is unusually large (Figure 2), and this positive shock to profitability provides firms a cash windfall with which to finance projects that they could not implement in the pre-liberalization period.

In order to further scrutinize the relation between investment and current sales evident in Table 2, we examine whether the correlation between investment and current sales growth during liberalization episodes is stronger than the correlation at any generic point in time. Specifically, we estimate the following regression:

$$
\begin{gathered}
\left(\frac{I}{K}\right)_{i j t}={\text { CONSTANT }+ \text { COUNTRY }_{j}+\beta_{1} \text { SALESGROWTH }_{i j t}} \\
+\beta_{2} \text { SALESGROWTH }_{i j t} * \text { LIBERALIZATION }_{i j t}+\varepsilon_{i j t} .
\end{gathered}
$$

In equation (9) the variable $t$ denotes calendar time, not liberalization time as in all of the other regression specifications. Accordingly, the left-hand-side variable is the growth rate of the real capital stock, not deviations of the growth rate from the mean as in equation (8). Similarly, the right-hand-side variable is the growth rate of current sales, not deviations of the growth rate from its mean. The reason for not using deviations is that equation (9) attempts to estimate the behavior of investment over the entire sample (not just the post-liberalization period) and deviations from the mean over the entire sample will, by definition, be equal to zero. If the responsiveness of investment to sales growth at a generic time, $t$, is the same as when $t$ is a liberalization year, then the coefficient on the interaction term should not be significant. 
Table 3 presents the results. The regression in Column (1) shows that both the coefficient on current sales growth and the interaction of current sales growth with the liberalization dummy are significant. The regressions in Columns (2) through (6) show that only the interaction term with current sales growth is significant. The question is how to interpret the finding that investment is particularly sensitive to current sales growth during liberalization periods.

If a firm faces financing frictions then investment will be sensitive to current cash flow. Importantly, the converse of the preceding statement need not be true. A firm's investment may be sensitive to cash flow, even in the absence of financial constraints that impede its ability to implement optimal investment decisions (Kaplan and Zingales, 1997, 2000; Stein, 2003). A number of models can account for the significant relation we find between investment and current profitability, and an attempt to distinguish between all of the competing explanations lies beyond the scope of this paper. ${ }^{5}$ Instead we ask the question most germane to the task at hand: Is there any evidence that a lack of access to external finance impedes the investment decisions of the firms in our sample? While access to external finance would not seem to be an issue for the 100 largest manufacturing firms in a country-large established firms with lots of tangible assets tend to have access to credit—we examine several variables that speak directly to the issue. ${ }^{6}$

Begin with dividends. A firm that pays dividends could invest more by cutting dividends, so it seems unlikely that a dividend-paying firm suffers from capital rationing (Lang and Stulz, 1994). All of the firms in our sample pay dividends. Furthermore, Row 1 of Table 4 shows that a significant increase in dividend issuance takes place following liberalization, and it seems unlikely that capital-constrained firms would increase dividends at the very moment investment opportunities are improving (as Figures 2 and 3 suggest they are). Next, turn to debt.

\footnotetext{
${ }^{5}$ See Stein (2003) for a review of the literature on capital market imperfections and corporate investment.

${ }^{6}$ Our analysis of access to external finance is similar in spirit to that of Johnson, McMillan and Woodruff (2002) and Rajan and Zingales (1998).
} 
All of the firms in our sample have long-term debt, which again does not suggest a lack of access to external finance.

To provide a more general picture of the extent to which the firms in our sample use external sources to finance investment, Table 4 lists several indicative variables: dividends, longterm debt, total external finance, retained earnings, and equity. We construct the ratio of the change in each variable to the change in the stock of net fixed assets (investment). We then calculate the average value of the ratio before liberalization, the average value after liberalization, and test whether the difference between the two averages is statistically significant. Table 4 shows that reliance on external finance rises in the aftermath of liberalizations, but not significantly so. Furthermore, there is a significant increase in reliance on internal funds.

Taken together with the evidence on the impact of current and future sales growth, the evidence in Table 4 suggests that the firms in our sample increase investment when future growth prospects improve, but they also increase investment when they have a lot of cash. These findings are roughly consistent with what we know about the investment behavior of firms in developed countries (Stein, 2003). Again, sorting through all of the alternative explanations of these facts lies beyond our ambit. The central point is that while financial constraints are surely an issue for some firms in the countries we study, there is no glaring evidence that a lack of access to external finance severely impedes the investment decisions of the 369 firms in our sample.

Having shown that lack of access to external finance cannot explain why firms' investment decisions are insensitive to changes in risk, we turn to other issues of robustness. 


\section{Robustness Checks}

This section performs several robustness checks. First, we explore whether the benchmark results in Table 2 are robust to the firm-specific scale effects mentioned in Section 4. Next, subsection 5A examines whether the panel regression estimations overstate the t-statistics on the stock price change coefficient. Finally, subsection 5B tests whether the results are sensitive to the definition of investment deviations.

The results in Table 2 do not adjust for the firm-specific scale effects we mentioned in Section 4. In order to examine the consequences of not doing so, we re-estimate a subset of the results using the following random coefficients specification:

$$
\begin{aligned}
& \Delta\left(\frac{I}{K}\right)_{i j t}=\text { CONSTANT }+ \text { COUNTRY } Y_{j}+a_{i} \sum_{\tau=1}^{3} \Delta S A L E S G R O W T H_{i j t+\tau}+\varepsilon_{i j t} \\
& \quad t \in\{[0],[+1],[+2],[+3]\} .
\end{aligned}
$$

Equation (10) differs from the benchmark specification, Equation (8), in two important ways. First, Equation (10) does not include changes in risk or any other purely cross-sectional variable on the right-hand-side, because random coefficients estimation requires time variation. Second, the coefficient on future sales growth deviations, $a_{i}$, is now firm-specific.

Random coefficients estimation calculates the coefficient on future sales growth deviations using a two-step procedure. The first step adjusts for firm scale effects in the following fashion. For a given firm, the random coefficients procedure uses the time variation in the future sales growth variable to generate an Ordinary Least Squares (OLS) regression coefficient. This coefficient measures the firm-specific effect of future sales growth deviations on investment. The first step is then repeated for each firm in the sample. The second step uses all of the firm-specific OLS estimates to create a single estimate of the effect of the right-hand- 
side variable on investment. It does so by using the $\lambda_{i}$ 's from equation (5) to generate a weighted average of the firm-specific OLS coefficients.

If scale effects are important, then the estimates of the coefficient on the future sales growth variable using the random coefficients procedure should differ substantially from the earlier estimates that do not adjust for scale effects. This is not the case. The earlier estimate (Column (2) of Table 2) produces a coefficient on future sales growth deviations of 0.315 that is significant at the one-percent level, and a constant of 0.019 that is significant at the five-percent level. The random coefficients procedure produces a coefficient on future sales growth deviations of 0.167 that is significant at the one-percent level, and a constant of 0.015 that is significant at the five-percent level.

\section{A. Are the Standard Errors on the Stock Price Change Variable Understated?}

While the results in Table 2 may be robust to random coefficients estimation, another potential concern is that the standard errors for the coefficient on the stock price change variable may be too low. To see the point, recall that the left-hand-side variable, firm-level investment, displays both cross-sectional and time series variation. In contrast, the stock-price-change variable is purely cross-sectional. Consequently, the panel regression framework estimates the coefficient on the stock-price change by repeatedly using the single observation of the stock price change for a given firm to match each time series observation of that firm's investment in the post-liberalization period. The potential problem with this procedure is that it effectively treats each repeated use of the stock price change as an independent observation. Consequently, the standard errors for the coefficient on the stock price change may be too small and the tstatistics too large. 
To address this concern, Table 5 collapses the panel regression into a purely crosssectional regression with time-series averages for the post-liberalization change in investment on the left-hand side. The results in Table 5 closely mirror those in Table 2. Post-liberalization changes in investment continue to be explained by changes in current and future sales growth and the common shock to the cost of capital. The effect of changes in risk remains insignificant. Of particular interest are the results reported in column (6), which confirm that liberalizationinduced stock price changes have a significant effect on investment; column (7) shows that the coefficient on the stock-price-change variable remains significant in the full-blown decomposition.

\section{B. Are the Results Sensitive to the Definition of Investment Deviations?}

Finally, it is also important to examine whether our measure of capital stock growth deviations is sensitive to the choice of the pre-liberalization window. If countries liberalize in response to crises or recessions, then using the three years immediately preceding the liberalization as a benchmark may overstate the abnormal growth rate of the capital stock in the post-liberalization period. Table 6 replicates all of the results in Table 2 using a new left-handside variable, which is defined as the growth rate of firm $i$ 's capital stock in year $t$ minus its average growth rate in the entire pre-liberalization period. The results in Table 6 are very similar to those in Table 2. The coefficients on current and future sales growth deviations are always significant, the constant and the coefficient on the stock price change during the liberalization year are often significant, and changes in risk never matter. 


\section{Conclusion}

Since there is little evidence to suggest that levels of expected stock returns in the US vary cross-sectionally according to the degree of firms' exposure to aggregate covariance risk, testing the hypothesis that firms in developing countries allocate physical investment in accordance with the CAPM may seem to fly in the face of all common sense. However, new evidence suggests that changes in firm-level stock returns during stock market liberalization episodes do reflect changes in covariance risk (Chari and Henry, 2004). And while the stock price changes that occur during liberalizations may convey information about changes in risk sharing, the more pressing economic question is whether investment responds accordingly. Because liberalizations reduce firms' risk premia, they should also encourage them to implement some projects that were too risky to adopt in autarky, a lá Obstfeld (1994).

We provide the first test of this prediction using firm-level data. The expression for the change in a firm's cost of capital, $\rho$, demonstrates why the data are not supportive:

$$
\Delta \rho_{i}=\left(r-r^{*}\right)+\gamma D I F C O V_{i}
$$

Suppose that liberalization reduces the risk-free rate by 10 percentage points and that $\gamma$, the coefficient of relative risk aversion is 2 . Since the average value of the change in a firm's covariance $(D I F C O V)$ in our sample is 0.015 , the average firm-specific change in the cost of capital will be about 3 percentage points ( 2 times 0.015 ). These numbers imply that the total fall in the cost of capital is 13 percentage points, but that the common shock accounts for roughly 80 percent of the change.

This simple numerical example illustrates a fundamental point. If the common shock dominates firm-specific shocks, then in order to detect a cross-sectional relationship between risk sharing and investment, changes in covariance must be precisely measured. Since changes in 
covariance are not precisely measured, the simple explanation of measurement error may account for our results. On the other hand, if the problem is not measurement error but that firms' capital allocation decisions are truly insensitive to risk, then Morck, Yeung, and Yu's (2000) result on the synchronicity of asset price movements in emerging markets may extend to synchronicity of real investment.

Yet it seems hard to argue that firm-specific information is entirely irrelevant for investment when the market allocates capital in accordance with various firm-specific proxies for changes in profitability. Furthermore, the common shock does help explain the postliberalization increases in investment, and there is some evidence to suggest that it signifies a change in the cost of capital. Regardless of how one chooses to interpret the evidence, it brings us a step closer to understanding whether investment is efficiently reallocated when countries remove barriers to international capital flows. Applied to better data in the future, the firm-level identification strategy developed here may bring us yet nearer. 


\section{References}

Baker, Malcolm, Jeremy C. Stein and Jeffrey Wurgler (2003). "When Does the Market Matter? Stock Prices and the Investment of Equity Dependent Firms." Quarterly Journal of Economics, Forthcoming.

Bekaert, Geert and Campbell R. Harvey (2000). "Foreign Speculators and Emerging Equity Markets." The Journal of Finance, 55 (2), 565-613.

Bekaert, Geert, Campbell Harvey and Christian Lundblad (2004). "Does Financial Liberalization Spur Growth?” Journal of Financial Economics, Forthcoming.

Bhagwati, Jagdish (1998). “The Capital Myth,” Foreign Affairs, May/June pp. 7-12.

Blanchard, Olivier J., C. Rhee, and Lawrence Summers (1993). “The Stock Market, Profit, and Investment." Quarterly Journal of Economics, 108, 115-36.

Booth, Laurence, Varouj Aivazian, Asli Demirguc-Kunt, and Vojislav Maksimovic (2001). "Capital Structures in Developing Countries." The Journal of Finance, 56(2), 87-130.

Chari, Anusha and Peter Blair Henry (2004). "Risk Sharing Asset Prices: Evidence From a Natural Experiment.” Journal of Finance, 59(3), 1295-1324.

Fama, Gene and Ken French (2004). “The CAPM: Theory and Evidence.” Journal of Economic Perspectives, 18(3), 25-46.

Fazzari, Steven M., R. Glenn Hubbard, and Bruce C. Petersen (1988). "Financing Constraints and Corporate Investment." Brookings Papers on Economic Activity, 1, 141-206.

Fischer, Stanley and Robert C. Merton. (1984). "Macroeconomics and Finance: The Role of the Stock Market," Carnegie-Rochester Conference Series on Public Policy, 21, 57-108.

Fischer, Stanley (2003). "Globalization and Its Challenges," American Economic Review, 93 (2), $1-30$.

Frankel, Jeffrey and David Romer (1999). "Does Trade Cause Growth?" American Economic Review 89 (3), 379-399.

Gujarati, Damodar N. (1988). Basic Econometrics, McGraw Hill, New York.

Hayashi, Fumio (1982). "Tobin's Marginal q and Average q: A Neoclassical Interpretation," Econometrica, 50(1), 213-24.

Henry, Peter Blair. (2000a). "Stock Market Liberalization, Economic Reform, and Emerging Market Equity Prices.” Journal of Finance, 55 (2), 529-64. 
Henry, Peter Blair (2000b). "Do Stock Market Liberalizations Cause Investment Booms?" Journal of Financial Economics, 58 (1-2), 301-334.

Henry, Peter Blair (2002). "Is Disinflation Good for the Stock Market?" Journal of Finance, 57 (4), 1617-1648.

Henry, Peter Blair (2003). "Capital Account Liberalization, The Cost of Capital, and Economic Growth." American Economic Review, 93 (2), 91-96.

Hubbard, R. Glenn (1998). "Capital Market Imperfections and Investment." Journal of Economic Literature, 36, 193-225.

Johnson, Simon, John McMillan and Christopher Woodruff (2002). "Property Rights and Finance." American Economic Review, 92 (5), 1335-1356.

Kaplan, Steven and Luigi Zingales (1997). "Do Investment-Cash Flow Sensitivities Provide Useful Measures of Financing Constraints?" Quarterly Journal of Economics, 112, 159216.

Kaplan, Steven and Luigi Zingales (2000). "Investment-Cash Flow Sensitivities Are Not Valid Measures of Financing Constraints." Quarterly Journal of Economics, 115, 707-712.

Lang, Larry H. P. and Rene M. Stulz (1994). "Tobin's q, Corporate Diversification, and Firm Performance" The Journal of Political Economy, 102 (6), 1248-1280.

Levine, Ross (2001). "International Financial Liberalization and Economic Growth" Review of International Economics, 9 (4), 688-702.

Li, Kan, Randall Morck, Fan Yang and Bernard Yeung (2004). "Firm-Specific Variation and Openness in Emerging Markets." Review of Economics and Statistics, Forthcoming.

Martell, Rodolfo and René M. Stulz (2003). "Equity Market Liberalizations as Country IPOs," American Economic Review 93 (2), 97-101.

Morck, Randall, Bernard Yeung, and Wayne Yu (2000). "The Information Content of Stock Markets: Why Do Emerging Markets Have Synchronous Stock Price Movements?" Journal of Financial Economics, 58 (1-2), 215-260.

Morck, Randall, David A. Strangeland, and Bernard Yeung (2000). "Inherited Wealth, Corporate Control, and Economic Growth: The Canadian Disease." In R. Morck, ed. Concentrated Corporate Ownership. NBER Conference Volume. University of Chicago Press

Obstfeld, Maurice (1994). "Risk-Taking, Global Diversification and Growth," American Economic Review, 84 (5),1310-1329. 
Obstfeld, Maurice (1998). “The Global Capital Market: Benefactor or Menace?” Journal of Economic Perspectives, 12 (4), 9-30.

Rajan, Raghuram and Luigi Zingales (1998). "Financial Development and Growth," American Economic Review, 88 (3), 559-86.

Rodrik, Dani (1998). Who needs capital account convertibility? Princeton Essays in International Finance 207, 55-65.

Rogoff, Kenneth (1999). "International Institutions for Reducing Global Financial Instability," Journal of Economic Perspectives, 13 (4), 21-42.

Shiller, Robert (1981). "Do Stock Prices Move Too Much to be Justified by Subsequent Changes in Dividends?" American Economic Review, 71(3), 421-436.

Shiller, Robert (2000). Irrational Exuberance. Princeton University Press, Princeton.

Singh, Ajit, Javed Hamid, Bahram Salimi, and Y. Nakano (1992). Corporate Financial Structures in Developing Countries, Technical paper \#1, International Finance Corporation, Washington, D.C.

Stein, Jeremy C. (2003). "Agency, Information and Corporate Investment" in the Handbook of the Economics of Finance, Constantinides, Harris and Stulz, eds., Forthcoming.

Stiglitz, Joseph (1999). "Reforming the Global Economic Architecture: Lessons From Recent Crises," Journal of Finance 54 (4), 1508-1521.

Stiglitz, Joseph (2002). Globalization and Its Discontents. W.W. Norton, New York.

Stulz, René M. (2005). “The Limits of Financial Globalization.” Journal of Finance, 60 (4), 1595-1638.

Stulz, René M. (1999). "International Portfolio Flows and Security Markets" in Martin Feldstein, ed. International Capital Flows. Chicago: University of Chicago Press.

Summers, Lawrence H. (2000). "International Financial Crises: Causes, Prevention, and Cures," American Economic Review, 90 (2), 1-16. 
Figure 1. Liberalization and The Growth Rate of Firms' Capital Stocks

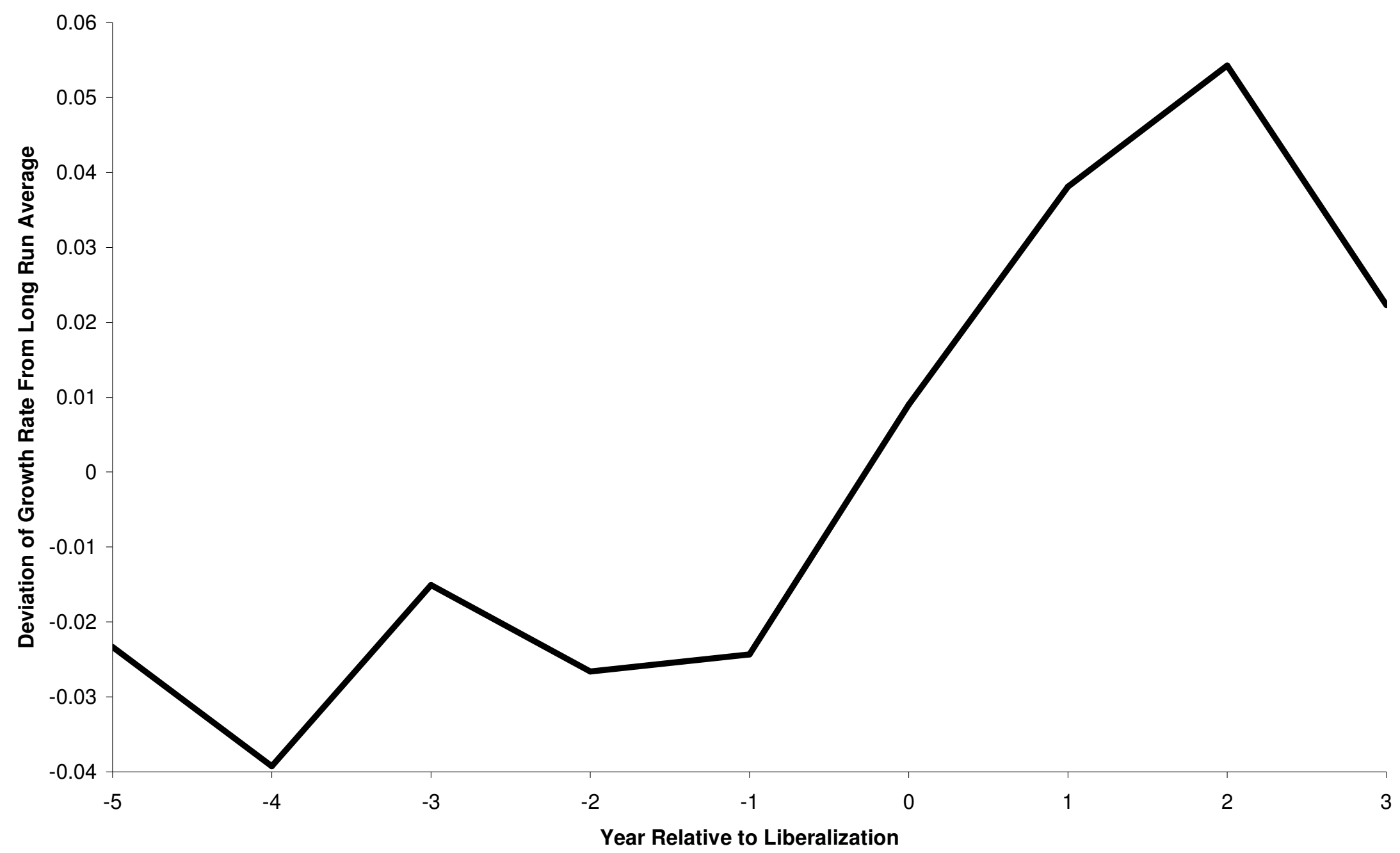

Figure 1. Capital stock growth is the growth rate of firm $i$ 's capital stock in year $t$ minus the average growth rate of firm $i$ 's capital in the entire period preceding the liberalization $(t=[-1,-5])$. The $y$-axis measures the average growth rate of the capital stock across the firms in our sample. The $\mathrm{x}$-axis measures time in terms of years relative to liberalization: $\mathrm{t}=0$ is the liberalization year; $\mathrm{t}=[-1,-5]$ is the pre-liberalization period and $\mathrm{t}=[+1,+3]$ is the post-liberalization period. 


\section{Figure 2. Liberalization and The Rate of Return to Firms' Capital}

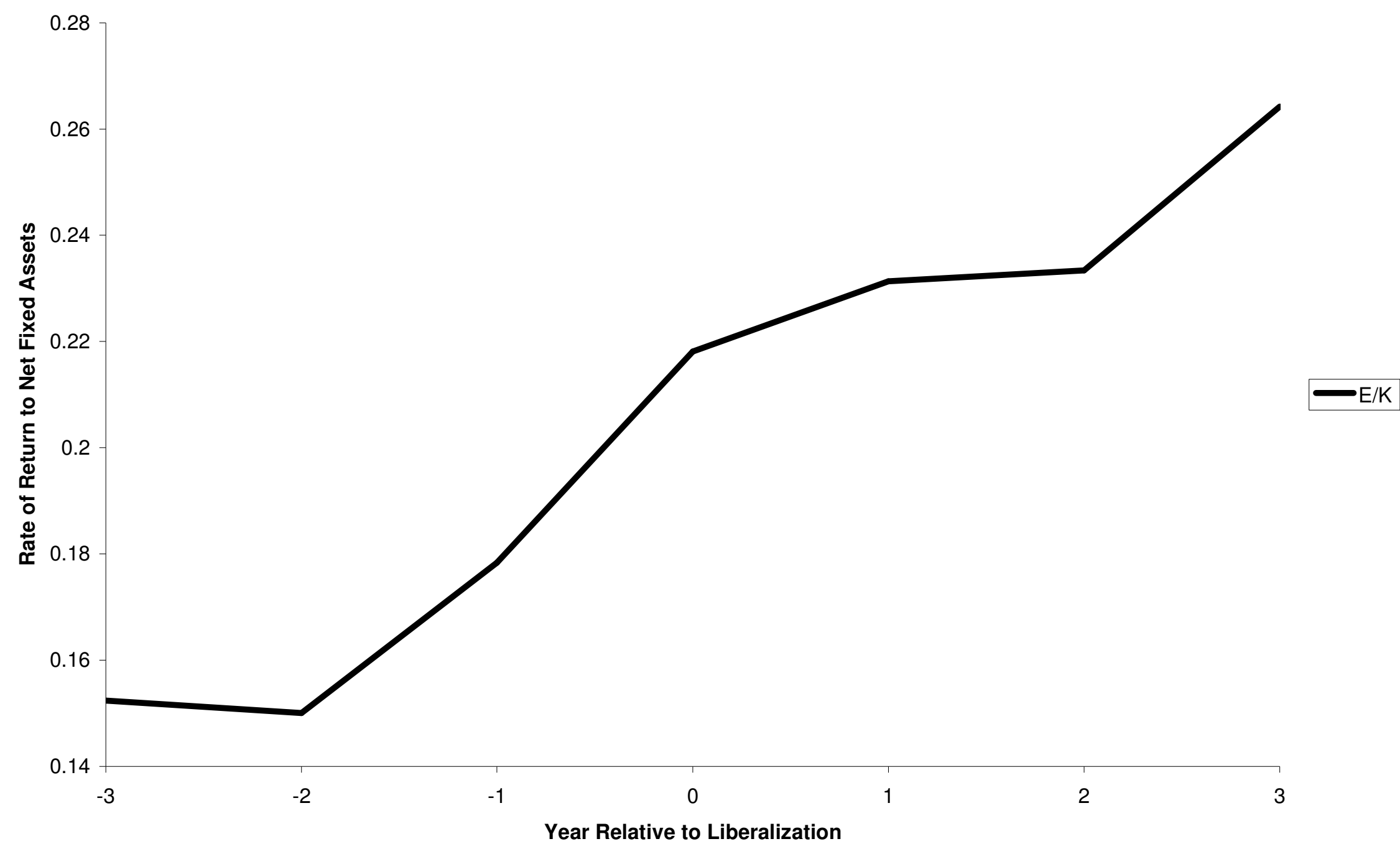

Figure 2. The $\mathrm{y}$-axis represents $\mathrm{E} / \mathrm{K}$ which is the average rate of return to net fixed assets or the aggregate rate of return to capital. For each firm, we compute the flow return to the stock of capital as the ratio of earnings before interest and taxes to the value of net fixed assets. E/K represents the average of this ratio across the 369 firms in our sample. The $x$-axis measures time in terms of years relative to liberalization: $t=0$ is the liberalization year; $t=[-1,-3]$ is the preliberalization period and $\mathrm{t}=[+1,+3]$ is the post-liberalization period. 
Figure 3. Liberalization and the Growth Rate of Firms' Sales and Earnings

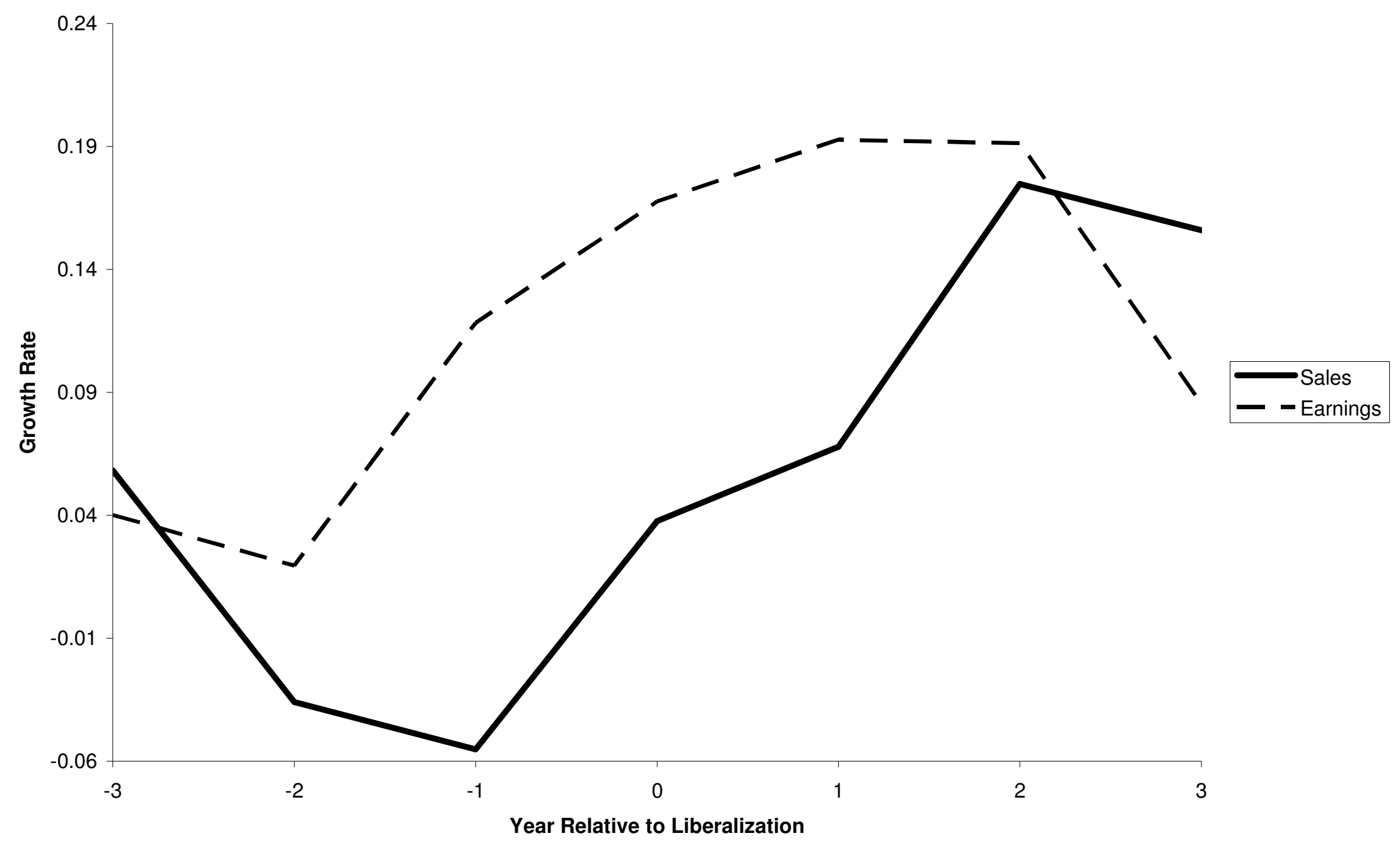

Figure 3. Sales and earnings growth are the first difference of the log of sales and earnings for any given firm. The y-axis measures the average growth rate of sales and earnings across the firms in our sample. The $\mathrm{x}$-axis measures time in terms of years relative to liberalization: $t=0$ is the liberalization year; $t=[-1,-3]$ is the pre-liberalization period and $\mathrm{t}=[+1,+3]$ is the post-liberalization period. 
Table 1. Descriptive Statistics.

\begin{tabular}{|c|c|c|c|c|}
\hline Country & Liberalization Year & Number of Firms & $\begin{array}{l}\text { Market Capitalization } \\
\text { of Firms as a Fraction of } \\
\text { Total Market Capitalization }\end{array}$ & $\begin{array}{l}\text { Percentage Change } \\
\text { in Tobin's } Q \text { During } \\
\text { Liberalization Year }\end{array}$ \\
\hline India & 1992 & 99 & 0.25 & 81.5 \\
\hline Jordan & 1987 & 35 & 0.14 & 9.6 \\
\hline Korea & 1987 & 89 & 0.38 & 57.7 \\
\hline Malaysia & 1987 & 85 & 0.45 & -28.5 \\
\hline Thailand & 1988 & 61 & 0.66 & 95.9 \\
\hline Full Sample & $1988 *$ & 369 & 0.40 & 46.1 \\
\hline
\end{tabular}


Table 2. Panel Estimations: The Impact of Changes in Firm-Fundamentals on Post-Liberalization Changes in Investment.

\begin{tabular}{|c|c|c|c|c|c|c|c|}
\hline $\begin{array}{l}\text { Right-Hand-Side } \\
\text { Variables }\end{array}$ & $(1)$ & $(2)$ & (3) & (4) & $(5)$ & $(6)$ & $(7)$ \\
\hline CONSTANT & $\begin{array}{l}0.041^{* * *} \\
(0.010)\end{array}$ & $\begin{array}{l}0.019 * * \\
(0.009)\end{array}$ & $\begin{array}{l}0.028^{* * *} \\
(0.011)\end{array}$ & $\begin{array}{l}-0.0003 \\
(0.009)\end{array}$ & $\begin{array}{l}-0.011 \\
(0.012)\end{array}$ & $\begin{array}{l}0.0004 \\
(0.013)\end{array}$ & $\begin{array}{l}-0.013 \\
(.011)\end{array}$ \\
\hline$\Delta S A L E S G R O W T H_{i j[0]}$ & & $\begin{array}{l}0.229 * * * \\
(0.047)\end{array}$ & & $\begin{array}{l}0.316 * * * \\
(0.047)\end{array}$ & $\begin{array}{l}0.213 * * * \\
(0.048)\end{array}$ & & $\begin{array}{l}0.268 * * * \\
(0.048)\end{array}$ \\
\hline$\sum_{\tau=1}^{3} \Delta S A L E S G R O W T H_{i j t+\tau}$ & & $\begin{array}{l}0.315^{* * * *} \\
(0.029)\end{array}$ & & $\begin{array}{l}0.287 * * * \\
(0.032)\end{array}$ & $\begin{array}{l}0.344 * * * \\
(0.032)\end{array}$ & & $\begin{array}{l}0.339 * * * \\
(0.033)\end{array}$ \\
\hline DIFCOV & & & $\begin{array}{l}0.037 \\
(0.195)\end{array}$ & $\begin{array}{l}-0.027 \\
(0.177)\end{array}$ & & & $\begin{array}{l}-0.069 \\
(0.184)\end{array}$ \\
\hline STOCKPRICECHANGE & & & & & $\begin{array}{l}0.0298 * * \\
(0.015)\end{array}$ & $\begin{array}{l}0.057^{* * *} \\
(0.016)\end{array}$ & $\begin{array}{l}0.042 * * * \\
(0.014)\end{array}$ \\
\hline Adjusted R-Squared & 0.01 & 0.088 & 0.00 & 0.09 & 0.10 & 0.01 & 0.12 \\
\hline Number of Observations. & 1293 & 1292 & 1080 & 1079 & 1184 & 1185 & 1054 \\
\hline
\end{tabular}

Notes: Table 2 presents results for alternative specifications of the benchmark regression, which is given by the following equation:

$$
\Delta\left(\frac{I}{K}\right)_{i j t}=\text { CONSTANT }+ \text { COUNTRY }_{j}+a_{0} \Delta S A L E S G R O W T H_{i j[0]}+a_{1} \sum_{\tau=1}^{3} \Delta S A L E S G R O W T H_{i j t+\tau}+b_{0} D I F C O V+\varepsilon_{i j t}, t \in\{[0],[+1],[+2],[+3]\} . \text { The left-hand- }
$$

side variable $\Delta\left(\frac{I}{K}\right)_{i j t}$ denotes the deviation of the capital stock growth of firm $\mathrm{i}$ (in country $\mathrm{j}$ ) from its firm-specific mean where $\mathrm{t}$ denotes years measured in liberalization time. $\triangle S A L E S G R O W T H_{i j[0]}$ is the deviation of the growth rate of firm i's sales from its firm-specific mean in year [0]. $\sum_{\tau=1}^{3} \triangle S A L E S G R O W T H_{i j t+\tau}$ is cumulative abnormal growth rate in firms i's sales in Years [+1], [+2], and [+3]. DIFCOV $V_{i}$ is the difference between the historical covariances of firm $i$ 's returns with the local and world markets. STOCKPRICECHANGE $E_{i}$ is the percentage change in firm $i$ 's real stock price during the liberalization year. COUNTRY represents a set of country specific dummies that control for country fixed effects. All specifications control for clustering in the error structure. The symbols $(* * *),(* *)$ and $(*)$ represent significance at the $1 \%, 5 \%$ and $10 \%$ levels, respectively. Standard errors are in parentheses. 
Table 3. Panel Estimates of Sales Growth-Investment Elasticities During Liberalization Years.

\begin{tabular}{|c|c|c|c|c|c|c|}
\hline Right-Hand-Side Variables & $(1)$ & $(2)$ & $(3)$ & $(4)$ & $(5)$ & $(6)$ \\
\hline SALESGROWTH & $\begin{array}{l}0.3072 * * * \\
(0.0186)\end{array}$ & & $\begin{array}{l}0.1593 * * * \\
(0.015)\end{array}$ & & $\begin{array}{l}0.1084 * * * \\
(0.016)\end{array}$ & $\begin{array}{l}01239 * * * \\
(0.015)\end{array}$ \\
\hline SALESGROWTH ${ }_{i j t} *$ LIBERALIZATION $_{i j t}$ & $\begin{array}{l}0.0555^{*} \\
(0.0302)\end{array}$ & & $\begin{array}{l}0.1788 * * * \\
(0.027)\end{array}$ & & $\begin{array}{l}0.2085 * * * \\
(0.028)\end{array}$ & $\begin{array}{l}01899 * * * \\
(0.0288)\end{array}$ \\
\hline SALESGROWTH & & $\begin{array}{l}0.1004 * * * \\
(0.0177)\end{array}$ & $\begin{array}{l}0.1158 * * * \\
(0.0154)\end{array}$ & & & $\begin{array}{l}01499 * * * \\
(0.016)\end{array}$ \\
\hline SALESGROWTH $_{i j(t+1)} * \operatorname{LIBERALIZATION}_{i j(t+1)}$ & & $\begin{array}{l}0.0316 \\
(0.0301)\end{array}$ & $\begin{array}{l}-0.021 \\
(0.028)\end{array}$ & & & $\begin{array}{l}-00559 \\
(0.0303)\end{array}$ \\
\hline SALESGROWTH & & & & $\begin{array}{l}0.0491 * * \\
(0.021)\end{array}$ & $\begin{array}{l}0.0579 * * * \\
(0.0164)\end{array}$ & $\begin{array}{l}0.070 * * * \\
(0.016)\end{array}$ \\
\hline SALESGROWTH $H_{i j(t+2)} * \operatorname{LIBERALIZATION}_{i j(t+2)}$ & & & & $\begin{array}{l}0.0141 \\
(0.034)\end{array}$ & $\begin{array}{l}-0.0386 \\
(0.035)\end{array}$ & $\begin{array}{l}-0.0547 \\
(0.0311)\end{array}$ \\
\hline Constant & $\begin{array}{l}0.0648 * * * \\
(0.006)\end{array}$ & $\begin{array}{l}0.1064 * * * \\
(0.005)\end{array}$ & $\begin{array}{l}0.0919 * * * \\
(0.005)\end{array}$ & $\begin{array}{l}0.1117 * * * \\
(.006)\end{array}$ & $\begin{array}{l}0.1035 * * * \\
(0.005)\end{array}$ & $\begin{array}{l}0.0862 * * * \\
(0.005)\end{array}$ \\
\hline R-squared & 0.13 & 0.03 & 0.08 & 0.02 & 0.05 & 0.08 \\
\hline
\end{tabular}

Notes: Table 3 presents results for the response of current investment to contemporaneous and future lags of sales growth, which is given by the following equation:

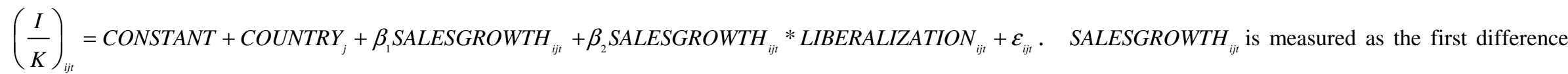

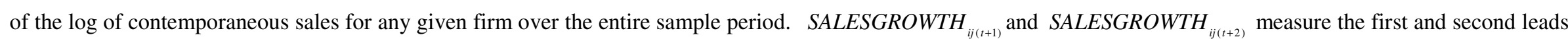

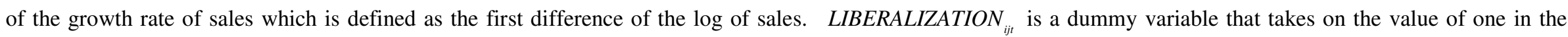

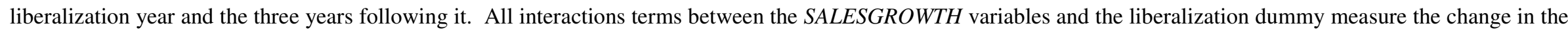

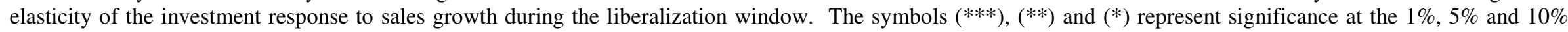
levels, respectively. Robust standard errors are in parentheses. 
Table 4. Pre and Post Liberalization Measures of Firms' Access to External Finance

\begin{tabular}{|c|c|c|c|}
\hline Variable & $\begin{array}{c}\text { Pre-Liberalization } \\
\text { Average }\end{array}$ & $\begin{array}{c}\text { Post-Liberalization } \\
\text { Average }\end{array}$ & $\begin{array}{c}\text { Post-Liberalization } \\
\text { Average Differs From } \\
\text { Pre? }\end{array}$ \\
\hline $\begin{array}{l}\text { Change in } \\
\text { Dividends/NFA }\end{array}$ & 0.0336 & 0.0525 & Yes*** \\
\hline $\begin{array}{l}\text { Change in Long-term } \\
\text { liabilities/change in NFA }\end{array}$ & 0.521 & 2.222 & No \\
\hline $\begin{array}{l}\text { Change in External } \\
\text { Finance1/Change in NFA }\end{array}$ & 0.237 & 1.357 & No \\
\hline $\begin{array}{l}\text { Change in External } \\
\text { Finance } 2 / \text { Change in NFA }\end{array}$ & 1.192 & 1.285 & No \\
\hline $\begin{array}{l}\text { Change in Retained } \\
\text { Earnings/Change in NFA }\end{array}$ & 0.516 & 1.534 & No \\
\hline $\begin{array}{l}\text { Change in Internal } \\
\text { sources/NFA }\end{array}$ & 0.015 & 0.080 & Yes* \\
\hline $\begin{array}{l}\text { Change in equity/change } \\
\text { in NFA }\end{array}$ & 0.363 & 1.026 & No \\
\hline
\end{tabular}

Change in dividends/NFA is the first difference of the log of the ratio of dividends divided by net fixed assets for each firm. External Finance1 for each firm is the sum of long-term liabilities and net worth less retained earnings. Change in external finance1 is the first difference of the log of external finance1 for each firm. Change in NFA is the first difference of the $\log$ of net fixed assets for each firm. External Finance 2 for each firm is the sum of total liabilities and net worth less retained earnings. Change in external finance 2 is the first difference of the log of external finance 2 for each firm. Change in retained earnings is the first difference of the log of retained earnings or total reserves for each firm. Internal sources is earnings after taxes less dividends paid for each firm. Change in internal sources/NFA is the first difference of the log of internal sources to net fixed assets for each firm. Equity is paid in capital or net worth less retained earnings. All changes are calculated on an annual basis for each firm. Pre-liberalization average is the average for any given variable across firms and countries for the period $t=-3$ to $t=-1$. Post-liberalization average is the average for any given variable across firms and countries for the period $t=0$ to $t=+3$. 
Table 5. Panel Estimations: The Impact of Changes in Firm-Fundamentals on Post-Liberalization Changes in Investment.

\section{Right-Hand-Side \\ Variables}

CONSTANT

$0.14 * * *$

(0.047)

$\triangle S A L E S G R O W T H_{i j[0]}$

$\sum_{\tau=1}^{3} \Delta S A L E S G R O W T H_{i j t+\tau}$

DIFCOV

\section{STOCKPRICECHANGE}

Adjusted R-Squared

0.01

0.085

0.176

(0.898)

(3)

(4)

$0.097 *$

(0.048)

0.018

(0.049)

$-0.048$

(0.062)

$0.003 \quad 0.062$

$0.317 * * *$

0.091

(0.132)

$0.369 * * *$

(0.064)

(0.127)

(0.136)

$0.386^{* * * *}$

$0.452 * * *$

$(0.069)$

(0.074)

$-0.303$

(0.887)

5)

(6)

(7)

$-0.049$

(0.058)

$0.221 *$

(0.130)

$0.456 * * *$

(0.075)

$-0.551$

(0.881)

$\begin{array}{lll}0.093 & 0.188 * * * & 0.121 * \\ (0.074) & 0.074 & (0.067)\end{array}$

Number of Observations.

377

360

0.001

0.12

0.11

0.02

0.15

$$
\Delta\left(\frac{I}{K}\right)_{i j}=\text { CONSTANT }+ \text { COUNTRY }_{j}+a_{0} \Delta S A L E S G R O W T H_{i j[0]}+a_{1} \sum_{\tau=1}^{3} \Delta S A L E S G R O W T H_{i j \tau}+b_{0} D I F C O V+\varepsilon_{i j t} \text {. The left-hand-side variable } \Delta\left(\frac{I}{K}\right) \text { denotes }
$$

the sum of the deviations of the capital stock growth of firm i (in country $\mathrm{j}$ ) in the liberalization year and the three years following it from its pre-liberalization firm-specific mean. $\triangle S A L E S G R O W T H_{i j[0]}$ is the sum of the deviation of the growth rate of firm i's sales from its pre-liberalization firm-specific mean in the liberalization year. $\sum_{\tau=1}^{3} \Delta S A L E S G R O W T H_{i j \tau}$ is cumulative abnormal growth rate in firms i's sales in the three years following liberalization. $D_{I F C O V_{i}}$ is the difference between the historical covariances of firm $i$ 's returns with the local and world markets. STOCKPRICECHANGE is the percentage change in firm $i$ 's real stock price during the liberalization year. COUNTRY, represents a set of country specific dummies that control for country fixed effects. All specifications control for clustering in the error structure. The symbols (***), (**) and (*) represent significance at the $1 \%, 5 \%$ and $10 \%$ levels, respectively. Standard errors are in parentheses. 


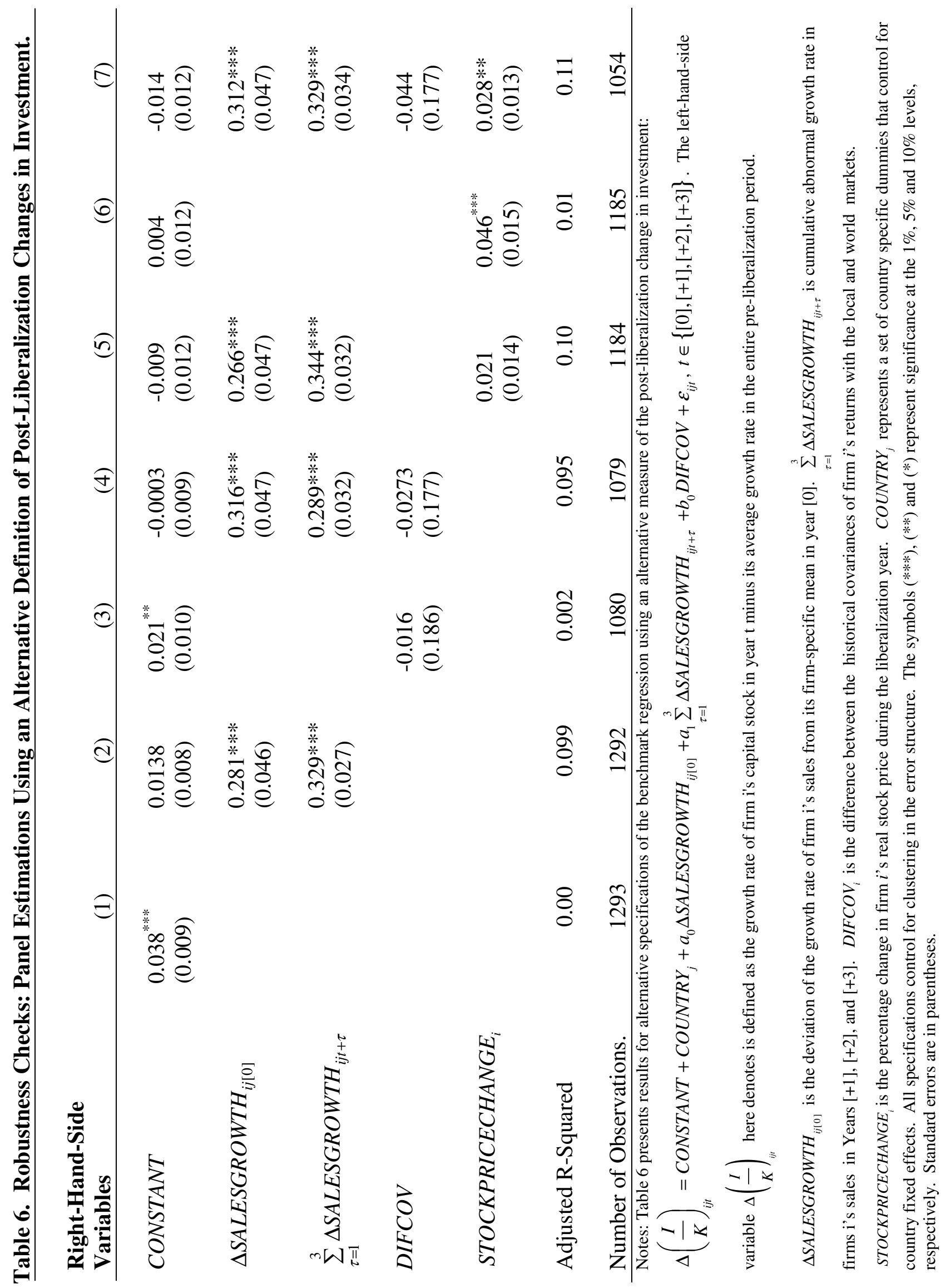

